\title{
Pseudomonas aeruginosa is capable of natural transformation in biofilms
}

3 Laura M. Nolan ${ }^{1,2}$, Lynne Turnbull ${ }^{1}$, Marilyn Katrib ${ }^{1}$, Sarah R. Osvath ${ }^{1}$, Davide Losa ${ }^{1}$ and Cynthia

B. Whitchurch ${ }^{1,3 *}$

Author affiliations:

${ }^{1}$ The ithree institute, University of Technology Sydney, Ultimo, New South Wales, 2007, Australia.

${ }^{2}$ National Heart and Lung Institute, Imperial College London, London, SW3 6LR, UK.

$9{ }^{3}$ Microbes in the Food Chain Programme, Quadram Institute Bioscience, Norwich Research Park,

10 Norwich, NR4 7UQ, UK

\section{* Corresponding author:}

13 Email: Cynthia.Whitchurch@quadram.edu.au

Current Addresses:

CBW: Microbes in the Food Chain Programme, Quadram Institute Bioscience, Norwich Research

LMN: National Heart and Lung Institute, Imperial College London, London, SW3 6LR, UK.

\section{Abbreviations:}


bioRxiv preprint first posted online Dec. 3, 2019; doi: http://dx.doi.org/10.1101/859553. The copyright holder for this preprint

(which was not peer-reviewed) is the author/funder, who has granted bioRxiv a license to display the preprint in perpetuity.

All rights reserved. No reuse allowed without permission.

\section{Abstract}

26 Natural transformation is a mechanism that enables competent bacteria to acquire naked, exogenous

DNA from the environment. It is a key process that facilitates the dissemination of antibiotic resistance and virulence determinants throughout bacterial populations. Pseudomonas aeruginosa is an opportunistic Gram-negative pathogen that produces large quantities of extracellular DNA (eDNA) that is required for biofilm formation. P. aeruginosa has a remarkable level of genome

31 plasticity and diversity that suggests a high degree of horizontal gene transfer and recombination but is thought to be incapable of natural transformation. Here we show that $P$. aeruginosa possesses

33 homologs of all proteins known to be involved in natural transformation in other bacterial species.

34 We found that $P$. aeruginosa in biofilms is competent for natural transformation of both genomic and 35 plasmid DNA. Furthermore, we demonstrate that type IV pili (T4P) facilitate but are not absolutely essential for natural transformation in P. aeruginosa. 
bioRxiv preprint first posted online Dec. 3, 2019; doi: http://dx.doi.org/10.1101/859553. The copyright holder for this preprint

(which was not peer-reviewed) is the author/funder, who has granted bioRxiv a license to display the preprint in perpetuity.

All rights reserved. No reuse allowed without permission.

\section{Introduction}

The continued increase in antimicrobial resistance (AMR) levels is considered to be a significant global threat ${ }^{1}$. Horizontal gene transfer $(\mathrm{HGT})$ is a key source of bacterial genome variation and evolution and is largely responsible for the acquisition of antibiotic resistance genes by bacterial pathogens $^{2}$. Bacteria can acquire and heritably incorporate new genetic information via three HGT mechanisms: conjugation, transduction and natural transformation. Conjugation is a cell-contact dependent mechanism that transfers DNA directly from the cytoplasm of one bacterial cell into another. Transduction involves encapsidation of DNA into a bacteriophage which then injects the DNA into the recipient cell. The third HGT mechanism is natural transformation which involves the import of naked DNA from the environment through a specialised DNA transport apparatus ${ }^{3,4}$.

In many naturally competent bacterial species Type IV pili (T4P) are required for natural transformation ${ }^{4}$. While the exact role of T4P in natural transformation is unclear, the generally accepted model is that DNA binds to the pilus structure, which retracts and pulls the DNA to the cell surface. It is unclear whether or not DNA is translocated across the outer membrane through the PilQ secretin pore. The incoming DNA can then be accessed by the ComEA DNA translocation machinery in the periplasm, which mediates DNA uptake possibly by a ratchet mechanism ${ }^{4,5}$. In Gram-positive bacterial species that do not produce T4P, natural transformation involves a number of proteins with homology to T4P proteins which are thought to form a pseudopilus structure that spans the cell wall and is coupled to the DNA translocation complex at the cytoplasmic membrane ${ }^{4,6}$. Once exogenous DNA has been taken up by the cell it can be stably incorporated into the genome via recombination or transposition, or be maintained as a plasmid if plasmid DNA is taken up by an appropriate host ${ }^{6}$.

Extracellular DNA (eDNA) is present in significant quantities in both clinical and environmental settings, and provides a vast reservoir of genetic material that can be sampled by bacteria that are competent for natural transformation ${ }^{7}$. 
bioRxiv preprint first posted online Dec. 3, 2019; doi: http://dx.doi.org/10.1101/859553. The copyright holder for this preprint

(which was not peer-reviewed) is the author/funder, who has granted bioRxiv a license to display the preprint in perpetuity.

All rights reserved. No reuse allowed without permission.

Pseudomonas aeruginosa is a highly antibiotic resistant Gram-negative bacterium which is a part of

the 'ESKAPE' group of pathogens that pose a serious health risk worldwide. $P$. aeruginosa readily acquires antibiotic resistance determinants, and demonstrates a high degree of genomic diversity and malleability similar to that seen in naturally transformable bacteria ${ }^{8,9}$. Despite this, $P$. aeruginosa has long been thought to be incapable of natural transformation ${ }^{10}$. P. aeruginosa is a model organism for studying T4P ${ }^{11}$. Interestingly, $P$. aeruginosa produces copious quantities of eDNA under conditions that promote T4P production such as in static broth cultures ${ }^{12}$, biofilms ${ }^{13}$ and during twitching motility-mediated biofilm expansion ${ }^{14,15}$. We therefore hypothesized that $P$. aeruginosa may be competent for natural transformation under conditions that promote both T4P expression and eDNA production. Here we show that some strains of $P$. aeruginosa are in fact capable of natural transformation under these conditions.

\section{Results}

Bioinformatic analyses of the sequenced P. aeruginosa strains PAO1, PA14 and PAK show that each of these strains encode homologs of all genes known to be involved in natural transformation in other bacterial species (Table 1). To determine if $P$. aeruginosa might be capable of natural transformation in biofilms, we established biofilms with a 1:1 mixture of PAO1 $1_{\mathrm{GFP}}\left(\mathrm{Gm}^{\mathrm{R}}\right)$ and PAO1 [pUCPSK] $\left(\mathrm{Carb}^{\mathrm{R}}\right)$ biofilms in $10 \mathrm{~cm}$ Tygon tubing under continuous flow conditions. Biofilm effluent was collected each day for 4 days and bacteria tested for their ability to grow on LB agar plates containing both gentamicin and carbenicillin. An average of $50-100 \mathrm{Gm}^{\mathrm{R}} / \mathrm{Carb}^{\mathrm{R}}$ colonies (resistant to both gentamicin and carbenicillin) were obtained from the effluent of mixed PAO1 ${ }_{\mathrm{GFP}}$ and PAO1 [pUCPSK] biofilms on day 1 and confluent lawns of $\mathrm{Gm}^{\mathrm{R}} / \mathrm{Carb}^{\mathrm{R}}$ colonies obtained from day 2

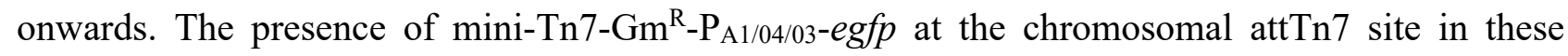
colonies was confirmed by PCR amplification. To confirm that these colonies also possessed 
bioRxiv preprint first posted online Dec. 3, 2019; doi: http://dx.doi.org/10.1101/859553. The copyright holder for this preprint

(which was not peer-reviewed) is the author/funder, who has granted bioRxiv a license to display the preprint in perpetuity.

All rights reserved. No reuse allowed without permission.

pUCPSK, plasmid DNA was extracted, transformed into E. coli and confirmed by sequencing. Neither the PAO1 $1_{\mathrm{GFP}}$ or PAO1 [pUCPSK] strains used to establish these mixed biofilms, or effluent from control single strain biofilms were able to grow on the dual antibiotic selection plates. As PAO1 lacks a prophage capable of transduction and pUCPSK is a non-conjugative plasmid, these results suggest that HGT of extracellular plasmid DNA and/or chromosomal DNA might occur via natural transformation in P. aeruginosa biofilms.

To determine if HGT of chromosomal DNA could occur via natural transformation, we established biofilms with a 1:1 mixture of PAO1 $1_{\mathrm{GFP}}\left(\mathrm{Gm}^{\mathrm{R}}\right)$ and PAO1 $1_{\mathrm{CTX}}\left(\mathrm{Tc}^{\mathrm{R}}\right)$ in $10 \mathrm{~cm}$ Tygon tubing under continuous flow conditions. Biofilm effluent was collected each day for 8 days and bacteria tested for their ability to grow on LB agar plates containing both gentamicin and tetracycline. Whilst no $\mathrm{Gm}^{\mathrm{R}} / \mathrm{Tc}^{\mathrm{R}}$ colonies were obtained from days $1-4$, from days $5-8$ an average of $3 \mathrm{Gm}^{\mathrm{R}} / \mathrm{Tc}^{\mathrm{R}}$ colonies that were resistant to both antibiotics and expressed GFP were recovered per day. The presence of both

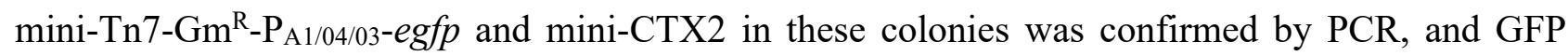
expression observed with epifluorescence imaging. Importantly, neither the PAO1 $1_{\mathrm{GFP}}$ or PAO1CTX strains used to inoculate the mixed biofilms or effluent from control single-strain biofilms were able to grow on the dual antibiotic selection plates. As neither conjugation or transduction is likely to account for these HGT events in PAO1 biofilms, these results suggest that PAO1 is able to acquire and incorporate chromosomal DNA and plasmids encoding antibiotic resistance genes via natural transformation in biofilms.

To confirm that $P$. aeruginosa is indeed capable of natural transformation and to rule out any possibility of HGT through transduction or conjugation, we performed a series of experiments to follow the uptake of purified, sterile exogenous DNA. We first grew wildtype strains PAK and PAO1 on LB agar overnight to form a colony biofilm on the surface of the agar. We then added $5 \mu \mathrm{g}$ of 
bioRxiv preprint first posted online Dec. 3, 2019; doi: http://dx.doi.org/10.1101/859553. The copyright holder for this preprint

(which was not peer-reviewed) is the author/funder, who has granted bioRxiv a license to display the preprint in perpetuity.

All rights reserved. No reuse allowed without permission.

113 sterile DNA (or the equivalent volume of sterile water) of the plasmid pUCPSK, onto the surface of

114 the colony biofilm. After $2 \mathrm{hr}$ incubation at $37^{\circ} \mathrm{C}$ the colony was resuspended and cells plated onto

115 media containing carbenicillin to select for transformants that had acquired the plasmid. Only colony

116 patches that had been exposed to plasmid DNA yielded $\mathrm{Carb}^{\mathrm{R}}$ colonies (Figure 1A), whereas colony

117 patches exposed to sterile water yielded none. The transformation efficiency for PAK and PAO1 was

$11824.7 \pm 10.1$ and $5.8 \pm 1.9$ transformants $/ \mu \mathrm{g}$ plasmid DNA, respectively. To confirm that the

119 carbenicillin resistant colonies had acquired pUCPSK, plasmid DNA was extracted, re-transformed

120 into E. coli and confirmed by sequencing. These observations indicate that a proportion of cells within

121 colony biofilms of $P$. aeruginosa are competent for natural transformation and are able to take up and

122 maintain plasmid DNA.

124 Given that both P. aeruginosa strains PAK and PAO1 appeared to be naturally competent, we wanted

to determine if this was also the case for other commonly utilised lab strains (PA14 and PA103) and

clinical isolates. All P. aeruginosa strains were first confirmed to be carbenicillin sensitive prior to use. Thirteen $P$. aeruginosa otitis externa and twelve cystic fibrosis (CF) lung sputum isolates were assayed for the ability to uptake pUCPSK plasmid DNA in a colony biofilm. Of these, 7/12 otitis externa and 6/10 CF isolates were able to uptake exogenous plasmid DNA (Figure 1B). No Carb ${ }^{\mathrm{R}}$ colonies were obtained in the no plasmid DNA controls for each strain. Interestingly, a range of 131 transformation efficiencies were observed in both clinical and lab strains. Of the lab strains, PA14 132 was the least capable of natural transformation with PAK the most efficient. These results 133 demonstrate that many lab and clinical isolate strains of $P$. aeruginosa are capable of natural 134 transformation within colony biofilms, albeit with different efficiencies.

$136 P$. aeruginosa also expresses T4P when cultured in static nutrient broth ${ }^{11}$. Under these conditions $P$. 137 aeruginosa forms biofilms and suspended microcolony aggregates that contain eDNA ${ }^{12}$. To 
bioRxiv preprint first posted online Dec. 3, 2019; doi: http://dx.doi.org/10.1101/859553. The copyright holder for this preprint

(which was not peer-reviewed) is the author/funder, who has granted bioRxiv a license to display the preprint in perpetuity.

All rights reserved. No reuse allowed without permission.

138 determine if natural transformation also occurred in broth cultures, $10 \mu \mathrm{g}$ of sterile pUCPSK plasmid

139 DNA (or the equivalent volume of sterile water) was added to a subculture of $P$. aeruginosa wildtype

140 PAK or PAOl and incubated statically at $37^{\circ} \mathrm{C}$ for $24 \mathrm{hrs}$ to allow biofilms and aggregates to form.

141 Cells were then recovered and plated onto media containing carbenicillin to select for transformants.

$142 \mathrm{Carb}^{\mathrm{R}}$ colonies were obtained for both PAO1 and PAK under these conditions, whereas no $\mathrm{Carb}^{\mathrm{R}}$

143 colonies were identified in the water control. As was observed with colony biofilm transformations

144 (Fig 1A), PAK was more efficient for natural transformation of pUCPSK than PAO1 in static broth 145 cultures (Fig 2A).

147 To determine if transformation efficiency was dependent on the amount of DNA added, we performed

148 static broth transformation assays with increasing amounts of plasmid DNA. Whilst we observed an 149 increase in the number of transformants with increasing amounts of plasmid DNA added (Figure 2C),

150 the transformation efficiency (transformants/ $\mu$ g DNA) was relatively unchanged over the range of 151 DNA quantities used for transformation $(0.1-30 \mu \mathrm{g})$ (Figure 2D).

P. aeruginosa produces more T4P when cultured in static broth cultures than under shaking conditions ${ }^{11}$. We investigated the effects on natural transformation efficiency of culturing under static or shaking conditions and found that although some natural transformation was still observed under 156 shaking conditions, more transformants were obtained with static culture conditions (Figure 2B), 157 consistent with a role of T4P in natural transformation. To directly examine the role of T4P in natural 158 transformation of $P$. aeruginosa, we added plasmid DNA to static broths of PAK mutants defective 159 in the production of the pilin subunit (pilA), in T4P assembly (pilV, pilQ, fimV) and in T4P retraction 160 (pilT). Interestingly, all T4P mutants were capable of some natural transformation of pUCPSK, 161 however a significant reduction in transformation efficiency compared to wildtype PAK was 162 observed (Figure 2E). No Carb $^{\mathrm{R}}$ colonies were identified in the no DNA controls. There was no 
bioRxiv preprint first posted online Dec. 3, 2019; doi: http://dx.doi.org/10.1101/859553. The copyright holder for this preprint

(which was not peer-reviewed) is the author/funder, who has granted bioRxiv a license to display the preprint in perpetuity.

All rights reserved. No reuse allowed without permission.

163

164

165

166

167

168

169

170

171

172

173

174

175

176

177

178

179

180

181

182

183

apparent difference in the transformation efficiency of mutants which either didn't have any surfaceassembled T4P (pilA, pilV, pilQ, fimV) or were unable to retract T4P (pilT) (Figure 2E). These suggest that in $P$. aeruginosa, T4P facilitate transport of DNA to the cell surface but are not essential for natural transformation of $P$. aeruginosa. Furthermore, these observations indicate that during natural transformation in P. aeruginosa the DNA is not being translocated through the PilQ secretin pore.

To further examine the hypothesis that $P$. aeruginosa cells within biofilms are competent for natural transformation, we examined plasmid DNA uptake under flow biofilm conditions. PAO1 flow biofilms were cultured in the presence or absence of purified pUCPSK plasmid DNA and the amount of natural transformation within the biofilm biomass and in the effluent assessed at days 3,4 and 5 . Natural transformation was observed in both the biofilm biomass and biofilm effluent (Figure 2F). No $\mathrm{Carb}^{\mathrm{R}}$ colonies were obtained in the no DNA control.

We have shown that $P$. aeruginosa is capable of natural transformation by uptake of exogenous plasmid DNA in colony biofilms, in static and shaking broth cultures and in flow biofilms (Figures 1, 2). We were also interested in determining whether $P$. aeruginosa was also able to uptake chromosomal DNA from the environment and integrate this into the chromosome. To examine this, chromosomal DNA from PAO1 $1_{\mathrm{GFP}}\left(\mathrm{Gm}^{\mathrm{R}}\right)$ was purified from either a whole cell lysate $(\mathrm{gDNA})$ or the total (sterile) eDNA from confluent agar plate culture and applied to static broth cultures of PAK or PAO1 for $24 \mathrm{hr}$. Cells were recovered and cultured on agar containing gentamicin to select for transformants. These assays revealed that natural transformation of gDNA occurred at a low frequency for both PAK and PAO1 in static broth cultures (Figure 3A). No natural transformation with sterile eDNA was observed in static broth cultures for either PAK or PAO1 (Figure 3A). This may be due to the integrity of the DNA as we observed via agarose gel electrophoresis that the eDNA used in these experiments was quite degraded compared with the gDNA, presumably through the 
bioRxiv preprint first posted online Dec. 3, 2019; doi: http://dx.doi.org/10.1101/859553. The copyright holder for this preprint

(which was not peer-reviewed) is the author/funder, who has granted bioRxiv a license to display the preprint in perpetuity.

All rights reserved. No reuse allowed without permission.

action of nucleases present in the extracellular milieu. No gentamicin resistant colonies were obtained in the no DNA controls.

We also examined if natural transformation by uptake of exogenous chromosomal DNA occurs in biofilms cultured under continuous flow. P. aeruginosa PAO1 flow biofilms were cultured in $10 \mathrm{~cm}$ Tygon tubing in the presence and absence of sterile gDNA or eDNA obtained from PAO1 $1_{G F P}\left(\mathrm{Gm}^{\mathrm{R}}\right)$ in the media influent. After 5 days the number of $\mathrm{Gm}^{\mathrm{R}}$ colonies recovered from the biofilm biomass were counted. This revealed extremely variable rates of natural transformation of gDNA by cells within the biofilm biomass across multiple experiments (Figure 3B). This is not unexpected as the rate is likely to be dependent upon the time at which the natural transformation event occurred. If this event occurred early in the assay, we would expect many transformants recovered due to proliferation of the transformed cells. However, if transformation occurred later we would expect far fewer transformants as these did not have as long to proliferate. For the eDNA experiments, while some $\mathrm{Gm}^{\mathrm{R}}$ transformants were obtained (Figure 3C), the rate of natural transformation was overall much lower than for gDNA (Figure 3B). No $\mathrm{Gm}^{\mathrm{R}}$ colonies were obtained for continuous flow biofilms in the absence of gDNA or eDNA indicating that the gentamicin resistant cells recovered from these assays was due to the presence of the exogenous chromosomal DNA. To further rule out the possibility of spontaneous resistance, the presence of the mini- $\mathrm{Tn} 7-\mathrm{Gm}^{\mathrm{R}}-\mathrm{P}_{\mathrm{A} 1 / 04 / 03}-\mathrm{eg} f p$ at the chromosomal att $\mathrm{Tn} 7$ site in the biofilm-derived $\mathrm{Gm}^{\mathrm{R}}$ colonies was confirmed by PCR. The presence of the $g f p$ gene in the $\mathrm{Gm}^{\mathrm{R}}$ colonies was also confirmed by visualisation of GFP expression using epifluorescence microscopy (Figure 4B). No GFP expression was observed in the PAO1 inoculum strain (Figure 4A). As it was not possible to directly visualise biofilms cultured in Tygon tubing, PAO1 continuous flow biofilms were cultured in transparent flow cells over 5 days in the presence and absence of gDNA obtained from PAO1 ${ }_{\mathrm{GFP}}$. Epifluorescence microscopy revealed microcolonies of GFP-expressing bacteria within the biofilm (Fig 4C-F). No GFP expression was observed in the no DNA control biofilms. 
bioRxiv preprint first posted online Dec. 3, 2019; doi: http://dx.doi.org/10.1101/859553. The copyright holder for this preprint

(which was not peer-reviewed) is the author/funder, who has granted bioRxiv a license to display the preprint in perpetuity.

All rights reserved. No reuse allowed without permission.

\section{Discussion}

216 Here we have demonstrated, in contrast to current dogma, that $P$. aeruginosa is capable of natural 217 transformation of both plasmid and chromosomal DNA under conditions that promote the expression 218 of T4P and eDNA production, such as in biofilms. We found that whilst T4P appear to be involved 219 in facilitating DNA uptake, T4P are not absolutely required for natural transformation in $P$. 220 aeruginosa. Furthermore, our data suggests that the PilQ secretin pore is not absolutely required for 221 translocation of DNA across the outer membrane in this organism. This is in contrast to the other 222 Gram-negative bacteria in which it appears that T4P and the secretin pore are required for natural 223 transformation.

The finding that $P$. aeruginosa is capable of natural transformation is a paradigm shift in our understanding of how this pathogen acquires genetic diversity. Indeed, recombination has recently been identified as a major means of genetic diversity in $P$. aeruginosa cystic fibrosis (CF) lung isolates although the source of DNA and the mechanism of HGT was not determined ${ }^{16}$. Natural transformation may be an important mechanism for the acquisition of antibiotic resistance and virulence genes in this ESKAPE pathogen and a significant contributor to the rapid increase in number of multidrug resistant $P$. aeruginosa strains that are an emerging problem worldwide.

\section{Methods}

\section{Strains, plasmids and growth conditions}

235 P. aeruginosa strains used in this study were PAO1 (ATCC 15692), PAK ${ }^{17}$, PA14 $^{18}$, PA103 ${ }^{19}$,

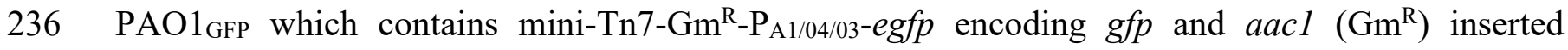


bioRxiv preprint first posted online Dec. 3, 2019; doi: http://dx.doi.org/10.1101/859553. The copyright holder for this preprint

(which was not peer-reviewed) is the author/funder, who has granted bioRxiv a license to display the preprint in perpetuity.

All rights reserved. No reuse allowed without permission.

238 site of the chromosome ${ }^{21}$ and T4P mutants PAKpilA::TcR $R^{22}$, and Tn5-B21 mutants of pilQ $Q^{23}$, pilT $^{24}$, 239 pil $^{25}$, fim $V^{26}$. The P. aeruginosa CF sputum clinical isolates were obtained from David Armstrong

240 at Monash Medical Centre (Melbourne, Australia), and the otitis externa P. aeruginosa clinical 241 isolates were obtained from Di Olden at Gribbles Pathology Melbourne (Australia). The pUCPSK 242 plasmid used is a non-conjugative E. coli-P. aeruginosa shuttle vector encoding bla which confers 243 carbenicillin resistance $\left(\mathrm{Carb}^{\mathrm{R}}\right)$ in $P$. aeruginosa ${ }^{27}$. E. coli Dh5a (recA, endA1, gyrA96, hsdR17, thi2441 , supE44, relA1, $\varphi 80$, dlacZAM15) was used as a host strain for pUCPSK and was miniprepped from $245 P$. aeruginosa and E. coli strains using a Qiagen miniprep kit according to manufacturer's 246 instructions.

P. aeruginosa was cultured on lysogeny broth (LB) solidified with agar at $1.5 \%(\mathrm{w} / \mathrm{v})$ for routine maintenance and at $1.5 \%$ or $1 \%(\mathrm{w} / \mathrm{v})$ for colony biofilm assays and grown in cation-adjusted Mueller Hinton Broth (CAMHB) at $37^{\circ} \mathrm{C}$ for all static broth and flow biofilm assays. Antibiotics were used at the following concentrations (w/v) as required: ampicillin $50 \mu \mathrm{g} / \mathrm{ml}$ for E. coli and carbenicillin $250 \mu \mathrm{g} / \mathrm{ml}$, gentamicin $100 \mu \mathrm{g} / \mathrm{ml}$ and tetracycline $100 \mu \mathrm{g} / \mathrm{ml}$ for $P$. aeruginosa.

\section{Bioinformatics and data and statistical analyses}

Homologs of proteins involved in natural transformation were identified in $P$. aeruginosa PAO1 using BLASTp ${ }^{28}$. The Pseudomonas.com resource ${ }^{29}$ and the PAK genome ${ }^{30}$ were used to identify $P$. aeruginosa orthologs.

Data was graphed and analyzed using Graph Pad Prism version 8.0. The number of replicates and any statistical tests are described in figure legends. 
bioRxiv preprint first posted online Dec. 3, 2019; doi: http://dx.doi.org/10.1101/859553. The copyright holder for this preprint

(which was not peer-reviewed) is the author/funder, who has granted bioRxiv a license to display the preprint in perpetuity.

All rights reserved. No reuse allowed without permission.

262 Overnight cultures of $P$. aeruginosa were grown in $2 \mathrm{ml} \mathrm{CAMHB}$ at $37^{\circ} \mathrm{C}$, shaking at $250 \mathrm{rpm}$. A 10

$263 \mu \mathrm{L}$ plastic loop was used to generate a $1 \mathrm{~cm}$ patch of the overnight culture on a dry $1 \%$ LBA plate.

264 This was then incubated overnight at $37^{\circ} \mathrm{C}$. The next day $10 \mu \mathrm{L}$ of DNA at the indicated concentration

265 was spotted onto the established colony biofilm and allowed to dry into the cells. The plate was then

266 incubated with the agar downwards at $37^{\circ} \mathrm{C}$ for the indicated time. After incubation the colony biofilm

267 was harvested from the plate into $1 \mathrm{~mL} \mathrm{LB}$, vortexed to resuspend and then incubated at $37^{\circ} \mathrm{C}$ for 30

$268 \mathrm{~min}$ to fully resuspend the cells. The cell suspension was then spread plated between two $150 \mathrm{~mm}$

269 LBA plates with appropriate antibiotic selection and incubated for $24 \mathrm{hr}$ at $37^{\circ} \mathrm{C}$.

\section{Static broth assay}

272 Overnight cultures of $P$. aeruginosa were grown in $2 \mathrm{ml} \mathrm{CAMHB}$ at $37^{\circ} \mathrm{C}$, shaking at $250 \mathrm{rpm} .40 \mu \mathrm{L}$ 273 of overnight culture was subcultured into $2 \mathrm{ml}$ fresh CAMHB with DNA added at the indicated 274 concentration. The media, cells and DNA were then mixed and incubated at $37^{\circ} \mathrm{C}$ statically for $24 \mathrm{hr}$. 275 Note for the shaking broth assay the same setup was used however the culture was incubated with 276 shaking at $250 \mathrm{rpm}$. In both cases after incubation the cell suspension was then spread plated between two $150 \mathrm{~mm}$ LBA plates with appropriate antibiotic selection and incubated for $24 \mathrm{hr}$ at $37^{\circ} \mathrm{C}$.

\section{Isolation of DNA for use in continuous flow biofilm assays}

280 Chromosomal DNA (gDNA) was purified from PAO1Tn7::gfp-aacl cells using the Epicentre ${ }^{\circledR}$ 281 Masterpure DNA purification kit. Extracellular DNA (eDNA) was purified from a confluent lawn of 282 PAO1Tn7::gfp-aacl cultured overnight on MacConkey agar containing 5\% (v/v) glycerol. Bacteria 283 were suspended in sterile phosphate buffered saline (PBS), centrifuged and the supernatant filtered 284 through $0.2 \mu \mathrm{m}$ PES membrane. eDNA present in the supernatant was further purified by removal of 285 proteins and ethanol precipitation as reported previously ${ }^{31}$. Sterility of all DNA samples was confirmed prior to use by plating onto LB agar. 
bioRxiv preprint first posted online Dec. 3, 2019; doi: http://dx.doi.org/10.1101/859553. The copyright holder for this preprint

(which was not peer-reviewed) is the author/funder, who has granted bioRxiv a license to display the preprint in perpetuity.

All rights reserved. No reuse allowed without permission.

\section{Continuous flow biofilm assays}

$10 \mathrm{~cm}$ lengths of Tygon laboratory tubing (2mm ID) were inoculated with 1/100 dilution of an

overnight culture of $P$. aeruginosa in CAMHB and allowed to attach for 2 hours under static

conditions after which continuous flow was commenced at a rate of $80 \mu \mathrm{L} / \mathrm{min}$ at room temperature.

Influent media was CAMHB containing either no added DNA or DNA added at a final concentration

293 of $1 \mu \mathrm{g} / \mathrm{mL}$ for pUCPSK plasmid DNA, or $0.5 \mathrm{mg} / \mathrm{mL}$ for gDNA or eDNA. At harvest, the attached biofilm was removed by sonication and biofilm-associated bacteria collected by centrifugation.

Transformants were selected by plating onto LB agar with appropriate antibiotic selection and incubated for $24 \mathrm{hr}$ at $37^{\circ} \mathrm{C}$. To visualise natural transformation by PAO1 continuous flow biofilms (Figure 4) of gDNA an IBIDI ${ }^{\circledR} \mu$-slide I (with flow kit) was inoculated and cultured as described for the Tygon tubing biofilms. Biofilms were imaged using an Olympus IX71 inverted research microscope fitted with phase contrast objectives and filtered halogen lamps for fluorescent imaging.

\section{Confirmation of natural transformation events from continuous flow biofilms}

The presence of mini-Tn7-Gm ${ }^{\mathrm{R}}-\mathrm{P}_{\mathrm{A1} / 04 / 03}-\mathrm{eg} f p$ at the chromosomal attTn7 site was confirmed by PCR using primers $\quad \operatorname{Tn} 7$-up (5'CGTATTCTTCGTCGGCGTGAC3') and $\operatorname{Tn} 7$-down (5'CGAAGCCGCCGACAAGGG3'). Expression of GFP was confirmed by epifluorescence aeruginosa, plasmid DNA was extracted from P. aeruginosa, transformed into E. coli, extracted and 
bioRxiv preprint first posted online Dec. 3, 2019; doi: http://dx.doi.org/10.1101/859553. The copyright holder for this preprint

(which was not peer-reviewed) is the author/funder, who has granted bioRxiv a license to display the preprint in perpetuity. All rights reserved. No reuse allowed without permission.

\section{Acknowledgements}

313 We thank Jacob Bertrand, Elizabeth Tran, Lisa MacAskill, Dervilla McGowan, Heather Smith and 314 Kate Rainzcuk for technical assistance and helpful discussions. L. M. N was supported by an Imperial 315 College Research Fellowship. D. L. was supported by the Swiss National Science Foundation (SNSF, 316 grant n. P2GEP3_161769). C. B. W. was supported by a National Health and Medical Research 317 Council of Australia (NHMRC) Career Development Award and a Senior Research Fellowship 318 (571905).

320 Author information

\section{Contributions}

L.M.N, L.T, M.K, S.R.O, D.L and C.B.W performed experiments. L.M.N, L.T and C.B.W analyzed data. C.B.W. provided project administration and funding. L.M.N. and C.B.W. wrote the manuscript.

Ethics declarations

326 The authors declare no conflict of interest.

\section{References}

329 1. O’Neill, J. Tackling drug-resistant infections globally: Final report and recommendations. $330 \quad$ (UK Government and Wellcome Trust, 2016).

331 2. Pallen, M. J. \& Wren, B. W. Bacterial pathogenomics. Nature 449, 835-842 (2007).

332 3. Davison, J. Genetic exchange between bacteria in the environment. Plasmid 42, 73-91 (1999).

333 4. Dubnau, D. \& Blokesch, M. Mechanisms of DNA uptake by naturally competent bacteria. 334 Annu. Rev. Genet. (2019). doi:10.1146/annurev-genet-112618-043641

335 5. Ellison, C. K. et al. Retraction of DNA-bound type IV competence pili initiates DNA uptake 
bioRxiv preprint first posted online Dec. 3, 2019; doi: http://dx.doi.org/10.1101/859553. The copyright holder for this preprint

during natural transformation in Vibrio cholerae. Nat. Microbiol. 3, 773-780 (2018).

6. Chen, I. \& Dubnau, D. DNA uptake during bacterial transformation. Nat. Rev. Microbiol. 2, 241-249 (2004).

7. Ibáñez de Aldecoa, A. L., Zafra, O. \& González-Pastor, J. E. Mechanisms and regulation of extracellular DNA release and its biological roles in microbial communities. Front. Microbiol. 8, 1390 (2017).

8. Kung, V. L., Ozer, E. A. \& Hauser, A. R. The accessory genome of Pseudomonas aeruginosa. Microbiol. Mol. Biol. Rev. 74, 621-641 (2010).

9. Shen, K. et al. Extensive genomic plasticity in Pseudomonas aeruginosa revealed by

10. Carlson, C. A., Pierson, L. S., Rosen, J. J. \& Ingraham, J. L. Pseudomonas stutzeri and related species undergo natural transformation. J. Bacteriol. 153, 93-99 (1983).

11. Whitchurch, C. B. in Pseudomonas Volume 4 Molecular Biology of Emerging Issues (ed. J. L. Ramos and R. C. Levesque) Springer USA: 139-188 (2006).

12. Allesen-Holm, M. et al. A characterization of DNA release in Pseudomonas aeruginosa

13. Whitchurch, C. B., Tolker-Nielsen, T., Ragas, P. C. \& Mattick, J. S. Extracellular DNA

14. Gloag, E. S. et al. Self-organization of bacterial biofilms is facilitated by extracellular DNA. Proc. Natl. Acad. Sci. USA 110, 11541-11546 (2013).

15. Turnbull, L. et al. Explosive cell lysis as a mechanism for the biogenesis of bacterial membrane vesicles and biofilms. Nat. Commun. 7, 11220 (2016). opportunistic human pathogen Pseudomonas aeruginosa. Genome Biol. Evol. 7, 18-34 (2014). 
bioRxiv preprint first posted online Dec. 3, 2019; doi: http://dx.doi.org/10.1101/859553. The copyright holder for this preprint

(which was not peer-reviewed) is the author/funder, who has granted bioRxiv a license to display the preprint in perpetuity.

All rights reserved. No reuse allowed without permission.

18. Rahme, L. G. et al. Common virulence factors for bacterial pathogenicity in plants and animals. Science 268, 1899-1902 (1995).

19. Liu, P. V. Exotoxins of Pseudomonas aeruginosa. I. Factors that influence the production of exotoxin A. J. Infect. Dis. 128, 506-513 (1973).

20. Klausen, M. et al. Biofilm formation by Pseudomonas aeruginosa wild type, flagella and type IV pili mutants. Mol. Microbiol. 48, 1511-1524 (2003).

21. Hoang, T. T., Kutchma, A. J., Becher, A. \& Schweizer, H. P. Integration-proficient plasmids for Pseudomonas aeruginosa: site-specific integration and use for engineering of reporter and expression strains. Plasmid 43, 59-72 (2000).

22. Watson, A. A., Mattick, J. S. \& Alm, R. A. Functional expression of heterologous type 4 fimbriae in Pseudomonas aeruginosa. Gene 175, 143-150 (1996).

23. Martin, P. R., Hobbs, M., Free, P. D., Jeske, Y. \& Mattick, J. S. Characterization of pilQ, a new gene required for the biogenesis of type 4 fimbriae in Pseudomonas aeruginosa. Mol. Microbiol. 9, 857-868 (1993).

24. Whitchurch, C. B., Hobbs, M., Livingston, S. P., Krishnapillai, V. \& Mattick, J. S. Characterisation of a Pseudomonas aeruginosa twitching motility gene and evidence for a specialised protein export system widespread in eubacteria. Gene 101, 33-44 (1991).

25. Alm, R. A. \& Mattick, J. S. Identification of a gene, pilV, required for type 4 fimbrial biogenesis in Pseudomonas aeruginosa, whose product possesses a pre-pilin-like leader sequence. Mol. Microbiol. 16, 485-496 (1995).

26. Semmler, A. B., Whitchurch, C. B., Leech, A. J. \& Mattick, J. S. Identification of a novel gene,. Microbiology (Reading, Engl.) 146 ( Pt 6), 1321-32 (2000).

27. Watson, A. A., Alm, R. A. \& Mattick, J. S. Construction of improved vectors for protein production in Pseudomonas aeruginosa. Gene 172, 163-164 (1996).

28. Altschul, S. F., Gish, W., Miller, W., Myers, E. W. \& Lipman, D. J. Basic local alignment search tool. J. Mol. Biol. 215, 403-410 (1990). 
bioRxiv preprint first posted online Dec. 3, 2019; doi: http://dx.doi.org/10.1101/859553. The copyright holder for this preprint

(which was not peer-reviewed) is the author/funder, who has granted bioRxiv a license to display the preprint in perpetuity.

All rights reserved. No reuse allowed without permission.

388 29. Winsor, G. L. et al. Enhanced annotations and features for comparing thousands of

Pseudomonas genomes in the Pseudomonas genome database. Nucleic Acids Res. 44, D646-53 (2016).

391 30. Cain, A. K. et al. Complete Genome Sequence of Pseudomonas aeruginosa Reference Strain PAK. Microbiol. Resour. Announc. 8, (2019).

31. Miller, S. A., Dykes, D. D. \& Polesky, H. F. A simple salting out procedure for extracting DNA from human nucleated cells. Nucleic Acids Res. 16, 1215 (1988). 
bioRxiv preprint first posted online Dec. 3, 2019; doi: http://dx.doi.org/10.1101/859553. The copyright holder for this preprint (which was not peer-reviewed) is the author/funder, who has granted bioRxiv a license to display the preprint in perpetuity.

All rights reserved. No reuse allowed without permission.

\section{Tables and Figures}

397 Table 1. Homologs of proteins involved in natural transformation in a range of bacteria.

\begin{tabular}{|c|c|c|c|c|c|c|c|}
\hline Competence Protein & \begin{tabular}{|l}
$\begin{array}{l}\text { Bacillus } \\
\text { subtilis }\end{array}$ \\
\end{tabular} & \begin{tabular}{|l|}
$\begin{array}{l}\text { Streptococcus } \\
\text { pneumoniae }\end{array}$ \\
\end{tabular} & \begin{tabular}{|l|}
$\begin{array}{l}\text { Haemophilus } \\
\text { influenzae }\end{array}$ \\
\end{tabular} & \begin{tabular}{|l|}
$\begin{array}{l}\text { Thermus } \\
\text { thermophilus }\end{array}$ \\
\end{tabular} & \begin{tabular}{|l}
$\begin{array}{l}\text { Pseudomonas } \\
\text { stutzeri }\end{array}$ \\
\end{tabular} & \begin{tabular}{|l} 
Neisseria \\
gonorrhoeae
\end{tabular} & \begin{tabular}{|l}
$\begin{array}{l}\text { Pseudomonas } \\
\text { aeruginosa* }\end{array}$ \\
\end{tabular} \\
\hline \multicolumn{8}{|l|}{$\begin{array}{l}\text { T4P/Competence } \\
\text { Pseudopilus }\end{array}$} \\
\hline Traffic NTPase(s) & ComGA & ComGA & PilB & PilF & PilT, PilU & PilF, PilT & PilB, PilT, PilU \\
\hline $\begin{array}{l}\text { Polytopic membrane } \\
\text { protein }\end{array}$ & ComGB & ComGB & PilC & PilC & PilC & PilG & PilC \\
\hline Pilins or pseudopilins & $\begin{array}{l}\text { ComGC, -GD, } \\
\text {-GE, -GG }\end{array}$ & CgIC, CgID & PilA & $\begin{array}{l}\text { PilA1, -A2, -A3, } \\
\text {-A4 }\end{array}$ & PilA1 & PilE, ComP & $\begin{array}{l}\text { PilA, -V, -W, -X, } \\
\text {-E, FimT, FimU }\end{array}$ \\
\hline Prepilin peptidase & ComC & CilC & PilD & PilD & & PilD & PilD \\
\hline Secretin/pilot & na & na & ComE & PilQ & & PilQ/PilP & PilQ/PilP \\
\hline \multicolumn{8}{|l|}{$\begin{array}{l}\text { DNA translocation } \\
\text { machinery }\end{array}$} \\
\hline DNA receptor & ComEA & ComEA & & ComEA & & ComE & PA3140 \\
\hline Membrane channel & ComEC & ComEC & Rec-2 & ComEC & ComA & ComA & PA2984 \\
\hline ATP-binding protein & ComFA & ComFA & & & ExbB & & PA2983 \\
\hline \multicolumn{8}{|l|}{ Other } \\
\hline & & & DprA (Smf) & & & & PA0021 \\
\hline & & & TfoX (Sxy) & & & & PA4703 \\
\hline & & & CRP & & & & Vfr \\
\hline & & & CyaA & & & & CyaA, СуаВ \\
\hline & & & ComM & & & & PA5290 \\
\hline & & & ComF & & & & PA0489 \\
\hline
\end{tabular}

*Using $P$. aeruginosa $\mathrm{PAO} 1$ gene nomenclature 
bioRxiv preprint first posted online Dec. 3, 2019; doi: http://dx.doi.org/10.1101/859553. The copyright holder for this preprint

A

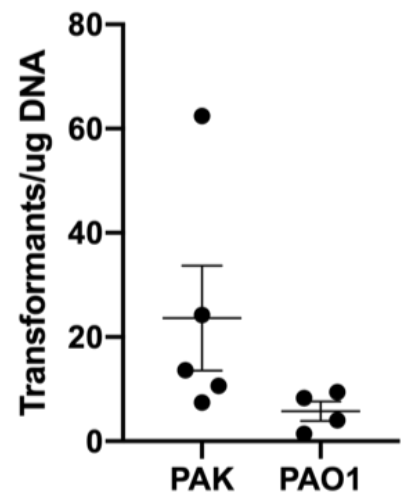

Figure 1. Lab and clinical strains of $P$. aeruginosa are capable of natural transformation of

plasmid DNA within colony biofilms. pUCPSK DNA was applied to colony biofilms of (A) $P$. plating on selective media. For (A) the mean of each set of technical triplicates was calculated to give an $\mathrm{n} \geq 4$ which is presented as mean \pm SEM. ( $P>.05$; Mann-Whitney $U$-test $)$. For $(\mathrm{B})$ the phenotype, NM is non-mucoid. 
A

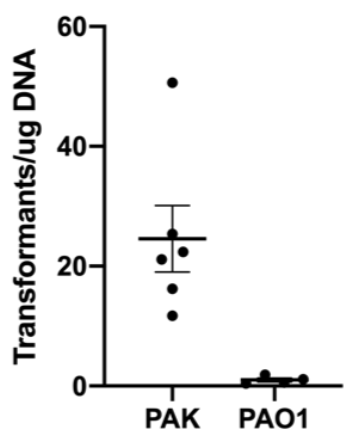

B

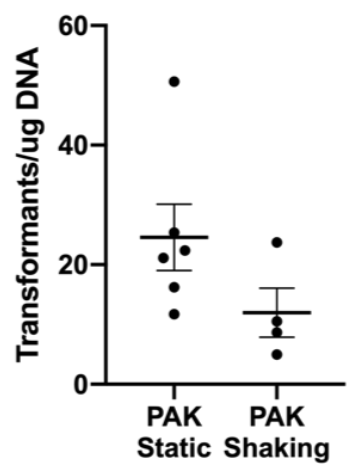

408
C

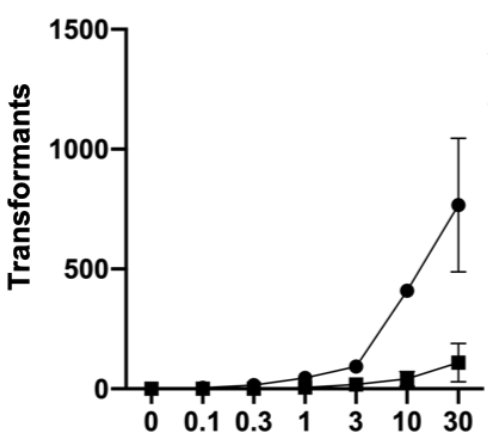

$\mu g$ DNA

D

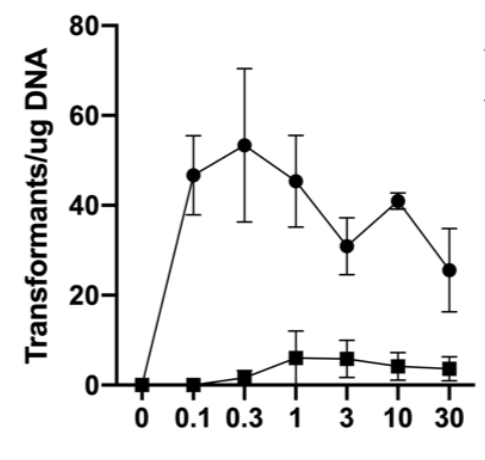

E

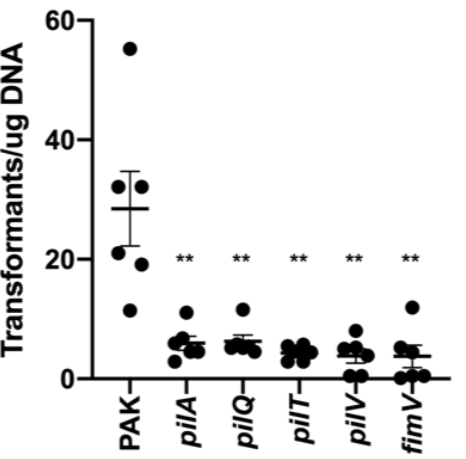

F
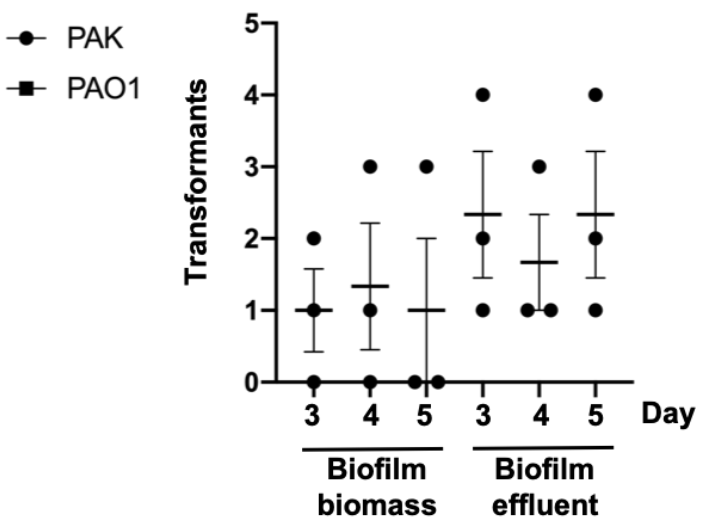

Figure 2. $P$. aeruginosa is capable of natural transformation of plasmid DNA in broth cultures and continuous flow biofilms. Carbenicillin resistant transformants obtained from static (A, C-E) or shaking (B) broth cultures incubated for $24 \mathrm{hr}$ with pUCPSK or (F) from biofilm biomass or effluent of PAO1 continuous flow biofilms cultured with pUCPSK in the media influent harvested on the indicated day. The mean of each set of technical triplicates was calculated to give an $n \geq 3$ which is presented as mean \pm SEM. For $(A)$ and $(\mathrm{E}) * * P<.005$; Mann-Whitney $U$-test compared to PAK. For (B) $P>.05$; Mann-Whitney $U$-test. 
A

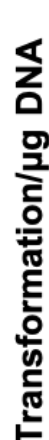

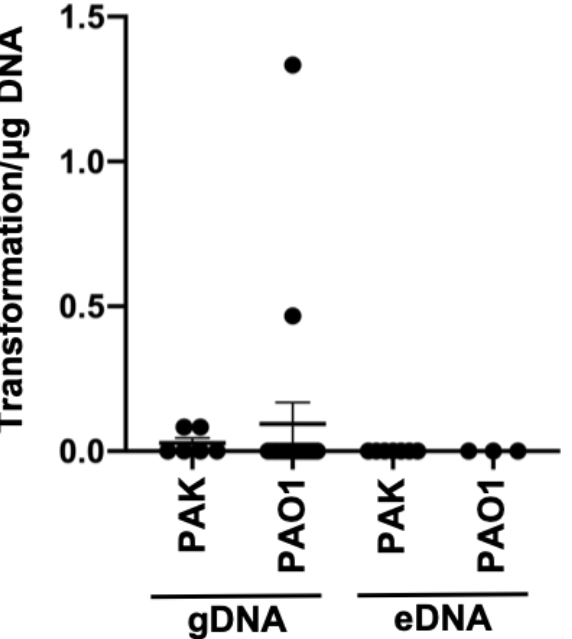

B

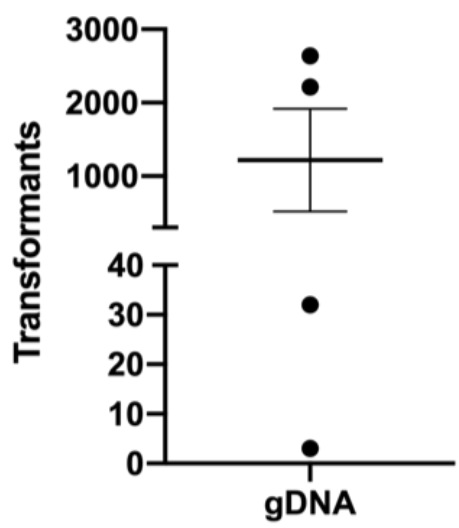

C

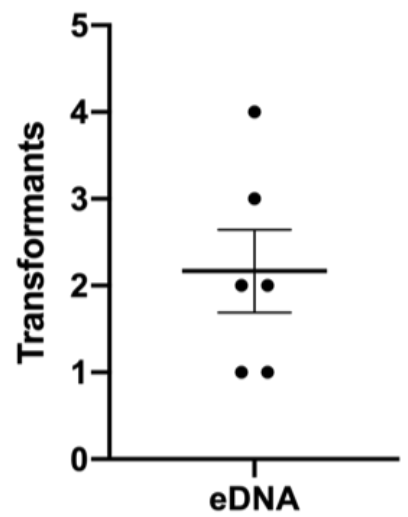

417 Figure 3. P. aeruginosa is capable of natural transformation of chromosomal DNA. Sterile

418 gDNA or eDNA was added to (A) static broth cultures of PAK or PAO1 and incubated for $24 \mathrm{hr}$ or

419 (B) in the media influent of continuous flow biofilms of PAO1 in Tygon tubing and incubated for 5

420 days. The mean of each set of technical triplicates was calculated to give an $n \geq 3$ which is presented $421 \quad$ as mean \pm SEM. 

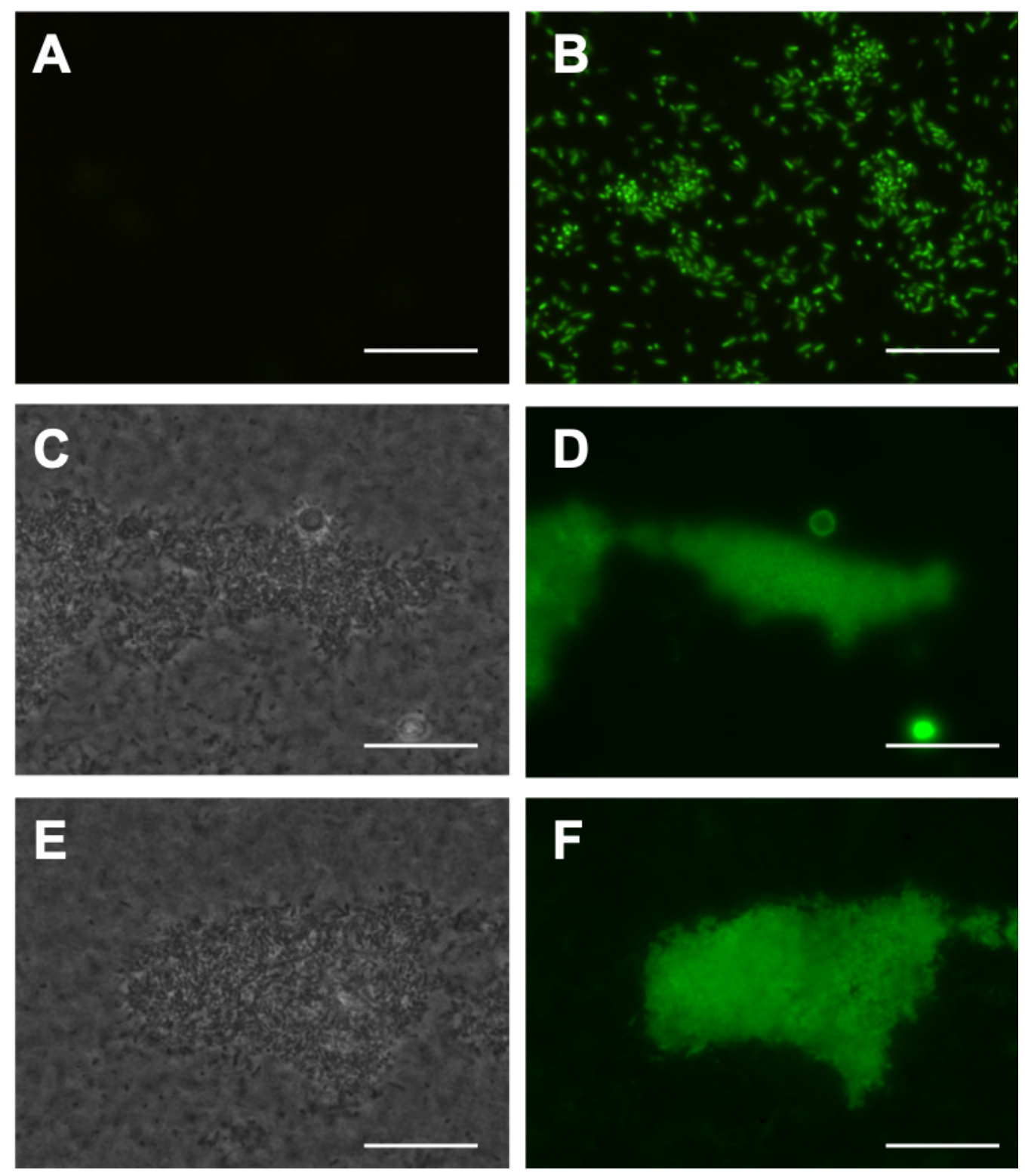

Figure 4. $P$. aeruginosa cultured in continuous flow biofilms can stably integrate and express antibiotic resistance and $g f p$ gene cassettes by natural transformation of exogenous

chromosomal DNA. Sterile PAO1 $1_{\mathrm{GFP}}$ gDNA was added to the media influent of continuous flow

biofilms of PAO1 in Tygon tubing (B) or flow cells (C-F) and incubated for 5 days. Gentamicin

resistant $\left(\mathrm{Gm}^{\mathrm{R}}\right)$ colonies obtained from Tygon tubing biofilms were resuspended in PBS and

visualized by epifluorescence microscopy which showed all cells from $\mathrm{Gm}^{\mathrm{R}}$ colonies expressed

GFP (B) whereas the inoculum PAO1 strain did not express GFP (A). The biofilm biomass in flow cells was visualized by phase contrast $(C, E)$ or epifluorescence microscopy $(D, F)$ which showed the presence of biofilm microcolonies expressing GFP. Scale bar $100 \mu \mathrm{m}$. 